\title{
RETRATO DE CINEASTA PINTANDO EN EL ESTUDIO: RELACIONES ENTRE PINTURA Y CINE EN DAVID LYNCH: THE ART LIFE (2016)
}

\author{
PORTRAIT OF A FILMMAKER PAINTING IN HIS \\ STUDIO: CONNECTIONS BETWEEN PAINTING AND \\ CINEMA IN DAVID LYNCH: THE ART LIFE (2016)
}

\author{
Ángel Justo Estebaranz \\ Universidad de Sevilla
}

\section{RESUMEN}

David Lynch: The Art life (2016) es un documental que supone un interesantísimo acercamiento a una figura tan fascinante como polifacética: David Lynch. Este film indaga en las primeras décadas de vida de quien, empezando su periplo artístico como pintor, desembocaría en el séptimo arte con una obra sugerente y perturbadora. En este trabajo se estudian las relaciones entre cine y pintura que se tejen en el documental, atendiendo al modo en que la obra pictórica del lynch pre y post cinematográfico va condicionando el discurso del propio director y de los autores del documental. Para ello, analizamos la película, así como las diferentes entrevistas concedidas por los directores, y diversas publicaciones de David Lynch que explican el sentido de su arte.

Palabras clave: David Lynch, documental, The Art Life, cine, pintura.

\begin{abstract}
David Lynch: The Art Life (2016) is a documentary film that involves an interesting approach to a fascinating and multifaceted figure: David Lynch. This film explores the first decades of life of a filmmaker with a suggestive and disturbing work, wich began his artistic career as a painter. In this paper we study the relations between cinema and painting that are shown in the documentary, taking into account the way in which the pictorial work of pre and post cinematographic Lynch is conditioned by the discourse of the filmmaker and the authors of the documentary. To do this, we analyze the film, as well as the different interviews given by the directors, and various publications by David Lynch explaining the meaning of his art.
\end{abstract}

Keywords: David Lynch, documentary, The Art Life, cinema, painting. 


\section{RESUM}

Retrat de cineasta pintant a l'estudi: relacions entre pintura i cinema a David Lynch: The Art Life (2016)

David Lynch: The Art life (2016) és un documental que suposa un interessantíssim apropament a una figura tan fascinant com polifacètica: David Lynch. El film indaga en les primeres dècades de vida de qui, començant pel seu periple artístic com a pintor, desembocaria en el sèptim art amb una suggeridora i pertorbadora obra. En aquest treball estudiem les relacions entre cine i pintura que es teixeixen al documental, tot atenent a com l'obra pictòrica del Lynch pre- i post- cinematogràfic condiciona el discurs del director mateix i dels autors del documental. Per tot allò, analitzem la pel.lícula, així com les diferents entrevistes concedides pels directors i diverses publicacions de David Lynch que expliquen el sentit del seu art.

Paraules clau: David Lynch, documental, The Art Life, cinema, pintura. 


\section{INTRODUCCIÓN: DAVID LYNCH, PINTOR Y CINEASTA}

David Lynch: The Art life es una película documental aparecida en 2016, que aborda las primeras tres décadas de vida del gran director de cine oriundo de Missoula (Montana). Muestra una época del artista anterior a su desembarco en el mundo del cine. A diferencia de otros acercamientos a su figura -ya sean en forma de ensayo, ya en forma de documental-, en esta ocasión no es su producción fílmica la que ocupa el metraje, sino su pasado, recordado por él mismo, y su práctica de la pintura. Lynch ha sido definido como un autor total. A pesar de ser mundialmente conocido por su contribución al cine y a la ficción televisiva, su obra va más allá: desde el cine a la música, pasando por la pintura, escultura, fotografía, collages, e incluso mobiliario o cómic. ' Él mismo se considera pintor. Antes de dedicarse al cine lo hizo a la pintura, y después ha seguido pintando. ${ }^{2} \mathrm{Si}$ con Inland Empire (2006) parece haber dado por concluida su labor como director de cine-que no de televisión, como demuestra la tercera temporada de Twin Peaks (2017), dirigida por él mismo y con guiones escritos conjuntamente con Mark Frost-, no ha hecho lo mismo con la pintura. Ejemplo

1 FERRER GARCÍA, Marcos Joaquín (2017), Lo siniestro como condición y límite del MRI. A propósito de David Lynch, Tesis Doctoral, Universitat Jaume I, Castellón de la Plana, p. 367. En su faceta como compositor de música electrónica destacan los álbumes Crazy Clown Time (2011) y The Big Dream (2013). Véase MEMBA, Javier (2017), David Lynch. El onirismo de la modernidad, Madrid, p. 12. En cuanto a su trabajo con el mobiliario, el documental lo muestra trabajando en una estantería, una mesa y un taburete, y admite que serrar madera en el comedor le encantaba, en la época en que se mudaron tras terminar su cortometraje The alphabet.

2 Memba compara esta actividad pictórica previa al cine, y su vuelta a la pintura tiempo después, con la del director italiano Michelangelo Antonioni. Véase MEMBA, David Lynch, p. 14. 
de ello es su trabajo actual, del cual se muestran en el film los lienzos que realiza durante las sesiones de grabación, así como otros que aparecen insertos en el metraje. Este trabajo le permite desarrollar un control total sobre la obra, algo que Lynch diferencia entre pintura y cine, medio en el que el director debe atender a las imposiciones y condicionantes que le vienen dados desde fuera. ${ }^{3}$ Es ese control absoluto sobre la obra pictórica una de las razones por las que Alm cree que su pintura permite una visión más profunda del pathos creativo de Lynch que su cine. ${ }^{4}$

A pesar de su voluntad de salvaguardar su arte de las acusaciones de ser "pintura de celebridades", tal como indica MacTaggart, en los últimos lustros han sido numerosas las exposiciones de su obra tanto en Estados Unidos como en Europa y Japón. ${ }^{5}$ Ya en 1989, el importante marchante Leo Castelli le organizó una exposición individual en su galería SoHo, criticada por algunos en razón de una supuesta "forzada ingenuidad de sus pinturas". ${ }^{6}$ En esa época, el realizador americano ya llevaba más de una década dedicada al cine, habiendo desarrollado un mundo muy personal que tiene conexiones con su faceta pictórica. El cine le permitió a Lynch añadir sonido y movimiento a la naturaleza inmóvil y muda de su pintura, y también una oportunidad de extender esta más allá de su marco. ${ }^{7}$ En este sentido, MacTaggart cree que la interconexión entre pintura, sonido y movimiento es integral en toda su obra cinematográfica posterior. Y ello lleva a ciertos autores a considerar la obra de Lynch como el mejor ejemplo de la influencia de la pintura en el cine. ${ }^{8}$ Por otra parte, Olson señala que muchas de las películas de Lynch son más bien pinturas cinematográficas que

3 LYNCH, David (2017), Atrapa el pez dorado, Sabadell, pp. 58-59. Ese control absoluto que busca Lynch y que le permite la pintura le llevó a considerar la página Web como un medio ideal para él. Por ello, creó su innovadora web www.davidlynch.com. Véase HOLDEN, Greg (2004), Internet Babylon: Secrets, Scandals, and Shocks on the Information Superhighway, eBook, p. 429.

4 ALM, David (2017), "The Creative Pathos Of David Lynch In 'The Art Life'", Forbes, https:// www.forbes.com/sites/davidalm/2017/03/31/the-creative-pathos-of-david-lynch-in-the-art-life/2/\#67227ba02de3 (Consultado el 13/05/2018). De este modo, el crítico opina que las películas de Lynch son, en todo caso, "versiones suavizadas de las pinturas en movimiento que Lynch desea hacer, atenuadas por ejecutivos de estudio por el bien de la comercialización".

5 MACTAGGART, Allister (2010), The Film Paintings of David Lynch: Challenging Film Theory, Bristol/Chicago, p. 11.

6 LIM, Dennis (2017), David Lynch. El hombre de otro lugar, Barcelona, p. 152.

7 MACTAGGART, The Film Paintings, p. 12.

8 PONCE TARRÉ, Jorge Esteban (2018), "Neofiguración e iconoclasia en el cine de David lynch", H-ART, vol. 3, p. 287. 
construcciones literarias. ${ }^{9}$ Hay críticos que ven una diferencia fundamental entre su pintura y su cine, y es la falta total de glamour en su pintura, la carencia de ese minimalismo elegante al que se refiere Livingstone. ${ }^{10}$

En su producción pictórica, Lynch se inspira en la obra de pintores tan diferentes como Duchamp, Magritte o Bacon. ${ }^{11}$ Pero su primera gran influencia en artes visuales fue su profesor Bushnell Keeler, en Virginia. Este profesor lo pondría sobre la pista del libro de Robert Henri The Art Spirit, que se convirtió para él en una biblia, ya que aportaba las reglas de la vida artística - -a la que precisamente da título el documental que analizamos en este trabajo-. ${ }^{12}$ Este libro sería para el joven Lynch "un símbolo de todo lo que es posible". ${ }^{13}$ Aunque el cineasta describe su juventud en términos amables al rememorar el apoyo de sus padres a su dedicación artística, $\mathrm{Ke}$ eler recuerda al Lynch adolescente como un joven con una batalla interior a causa de las tensiones familiares originadas por su obsesión por hacer arte. ${ }^{14}$ Francis Bacon es una influencia directa, como reconocía el director que consideraba su obra perfecta. Para él, en su juventud lo único que le interesaba era pintar y vivir la vida artística. ${ }^{15}$ La contemplación directa de la pintura de Bacon supuso un fuerte golpe para el adolescente de dieciocho años. Y muchos aspectos de la obra del pintor irlandés tendrían

9 OLSON, Greg (2008), David Lynch: Beautiful Dark, Lanham, p. 188

10 LIVINGSTONE, Josephine (2017), "The Organic, Violent Comedies of a Young David Lynch". The New Republic, 31/03/2017 https://newrepublic.com/article/141771/organic-violent-comedies-young-david-lynch (Consultado el 01/05/2018).

11 BILBAO, Javier (2017), "David Lynch: The Art Life", JotDown http://www.jotdown. es/2017/03/david-lynch-the-art-life/ (Consultado el 14/04/2018). En el capítulo 7 de On the Air, el propio Lynch evoca reverencialmente los nombres de Marcel Duchamp y de Man Ray, artistas de los que se consideraba compañero de viaje. Véase OLSON, David Lynch, pp. 402-403.

12 Entrevista con Kristine McKenna realizada en 1992, publicada en BARNEY, Richard A. (2009), David Lynch: Interviews, Jackson, p. 128. Según Costa, con este libro descubrió Lynch cuál iba a ser su lugar en el mundo y qué necesitaba para ser feliz: "café, tabaco y un lienzo o, dicho de otra manera, una vida de artista". Véase COSTA, Jordi, "Oscuridad y esplendor", El País, 31/03/2017 https://elpais.com/cultura/2017/03/29/actualidad/1490809056_747349.html (Consultado el 21/04/2018).

13 LIM, David Lynch, p. 12.

14 OLSON, David Lynch, p. 13.

15 Entrevista concedida en 1990 a David Breskin, publicada en BARNEY, David Lynch, p. 67. 
su influencia en la estética de Lynch: el espesor textural y la belleza de la pintura, así como el balance asimétrico de elementos fuertemente contrastados. ${ }^{16}$ La atmósfera a la vez seductora y siniestra de los lienzos de Bacon se deja notar en la obra de Lynch. De hecho, el propio Lynch valora las texturas maravillosas de elementos tan dispares como una corteza de árbol, un bicho, un trozo de tarta o incluso los cuerpos en descomposición. ${ }^{17}$ El valor que Lynch concede al trabajo de las texturas es apreciable a lo largo de varias escenas en el "presente" del documental que estudiamos, en el que se muestra al autor trabajando. Aborda obras sobre diferentes soportes, y utilizando materiales diversos que confieren a su obra un sello característico: una materialidad evidente. Para estos trabajos dispone de lo que él denomina una "instalación", es decir, un espacio que reúna las condiciones y herramientas necesarias para llevar a cabo la idea que se le haya podido ocurrir. ${ }^{18}$ En su casa de Hollywood Hills, en la que está rodado el documental, cuenta con estas instalaciones, que se muestran durante el film que estudiamos (Fig. 1). De esta manera evita que esas ideas se terminen diluyendo por falta del lugar y de las herramientas apropiadas para trabajarlas mientras dura la inspiración.

Otras influencias pictóricas en la obra de Lynch son Oskar Kokoschka, con quien pretendió estudiar, ${ }^{19}$ y los expresionistas abstractos, particularmente Jackson Pollock, Franz Kline y Jack Tworkov. ${ }^{20}$ Junto a los artistas antes mencionados, cabe destacar las visitas que el joven pintor realizó a la morgue en Filadelfia, que se convertirían en un punto de inflexión en su trabajo, como veremos más adelante. ${ }^{21}$ Por su parte, el surrealismo, que se considera muy presente en la obra cinematográfica y televisiva de

16 OLSON, David Lynch, p. 18. La influencia de Bacon en la obra del Lynch cineasta y televisivo, concretamente en Twin Peaks, ha sido brevemente apuntada por Pintor Iranzo en relación a los rostros sollozantes, compungidos y desfigurados de sus habitantes. Véase PINTOR IRANZO, Iván (2017), "El morador del umbral, un espectador para Twin Peaks", en CRISÓSTOMO, Raquel y ROS, Enric (coords), Regreso a Twin Peaks, Madrid, p. 208.

17 LYNCH, Atrapa el pez dorado, p. 100.

$18 \mathrm{LYNCH}$, Atrapa el pez dorado, p. 103.

19 MEMBA, David Lynch, p. 25.

20 OLSON, David Lynch, p. 31. Este autor también señala a Ed Ruscha, cuyas pinturas y las ficciones de Lynch comparten "tensión de oposición e interacción entre zonas y fuerzas de seguridad y peligro, luz y oscuridad" (p. 489).

21 Entrevista concedida a David Breskin en 1990, reproducida en BARNEY, David Lynch, p. 69 Lynch considera que en ese momento, la vida artística para él estaba relacionada con la vida en la ciudad americana. Sobre las visitas de Lynch a la morgue durante su etapa en Filadelfia, véase LIM, David Lynch, p. 47. 


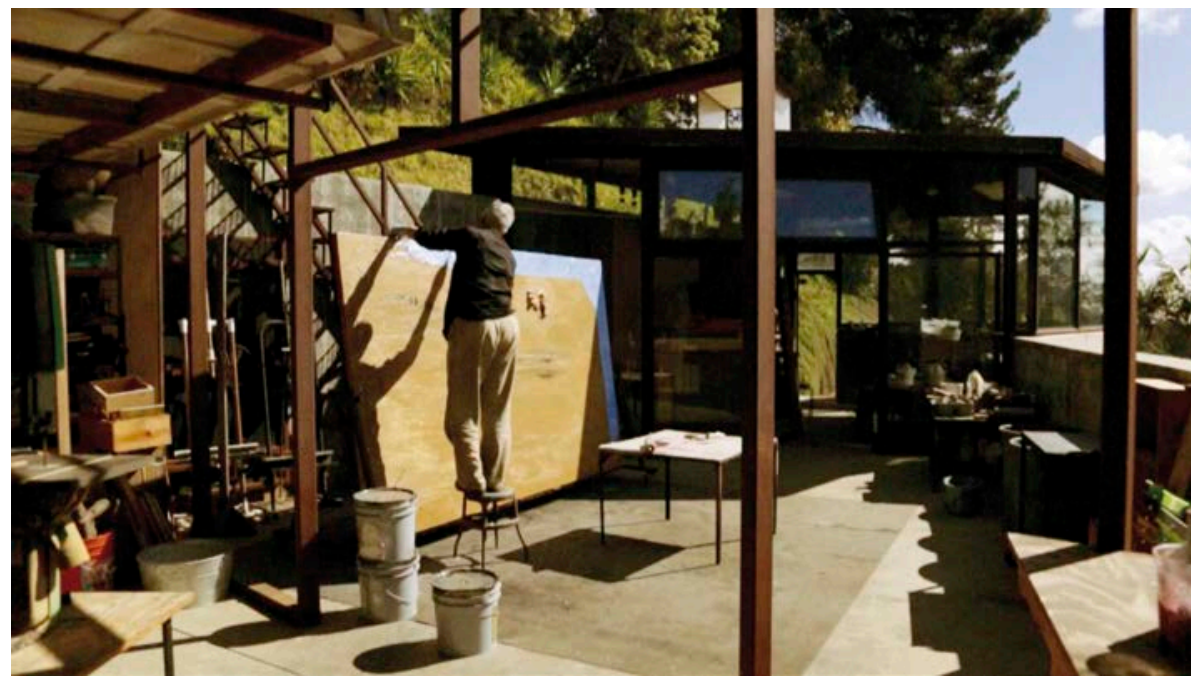

Fig.- 1. David Lynch trabajando en su estudio (Foto: Vértigo Films)

Lynch, es una influencia posterior, no de su juventud. De hecho, reconoció no haber visto Un perro andaluz hasta mucho tiempo después de realizar Eraserhead, que considera como una película abstracta, no surrealista. ${ }^{22}$ Estas influencias, así como la particular forma de asumirlas y reinterpretarlas, aplicando ideas y conceptos tanto a su pintura como a su cine, lo convertirían en el "zar de lo extraño", tal como lo definió la revista Time en $1990 .{ }^{23}$ En cualquier caso, el corpus para cine y televisión del cineasta americano tendría un fuerte sesgo surrealista, como demuestra la serie Twin

22 Película en la que pudo trabajar gracias a la beca del American Film Institute que había ganado previamente. Véase BRADSHAW, Peter (2017), "David Lynch: The Art Life review - portrait of a film-maker like no other", The Guardian, 14/07/2017 https://www.theguardian.com/ film/2017/jul/14/david-lynch-the-art-life-review-documentary (Consultado el 21/04/2018). A pesar de la opinión de Lynch sobre su propia película, son muchos los autores que la consideran surrealista. Véase, por ejemplo, KATZ, Ephraim (1998), The Macmillan International Film Encyclopedia, Londres, p. 859.

23 Esta publicación llegó a sacar al cineasta en portada en 1990. Véase LIM, David Lynch, p. 14. Por su parte, Carmona considera al cineasta también como un genuino creador de mundos propios y criaturas extrañas, como ya demostró en Eraserhead. Véase CARMONA, Luis Miguel (2012), Música \& Cine. Las grandes colaboraciones entre director y compositor, Madrid, p. 29. Precisamente, para crear estos mundos, "oníricos y tenebrosos", y cada vez "más delirantes", se apoyaría en la música de Angelo Badalamenti. Véase CARMONA, Luis Miguel (2008), Diccionario de compositores cinematográficos, Madrid, p. 44. 
Peaks, donde mezcló la estética surrealista tan característica de su producción con "un serial melodramático impregnado de tintes de cine negro". ${ }^{24}$ Junto a estas influencias, para ciertos autores el cine de Lynch también bebe de la pintura de Edward Hopper -por ejemplo en la América representada en Corazón salvaje-, el pintor que "supo captar con sus pinceles lo más cinematográfico de la América profunda" ${ }^{25}$ Los motivos de la violencia y la soledad, presentes respectivamente en la obra de Bacon y de Hopper, aparecen de forma clara en la filmografía de Lynch. ${ }^{26}$

En David Lynch: The Art life, muchas de estas influencias en su producción pictórica no aparecen referidas explícitamente, y se opta por subrayar la absoluta singularidad de Lynch. ${ }^{27}$ Sí cita expresamente a Bushnell Keeler, su mentor, y sus visitas a la morgue, así como a Oskar Kokoschka. Además, subraya la influencia de El espíritu del arte, el libro de Robert Henri, que conoció a través de Keeler. El relato de sus visitas a la morgue y la vinculación con la pintura seleccionada se puede relacionar con una cita de Lynchen su libro Atrapa el pez dorado: "Si quieres pescar pececitos, puedes permanecer en aguas poco profundas. Pero si quieres pescar un gran pez dorado, tienes que adentrarte en aguas más profundas. En las profundidades, los peces son más poderosos y puros. Son enormes y abstractos. Y muy bellos". ${ }^{28}$ Esto es lo que Lynch quiere buscar en su cine $y$ en su pintura, y lo hace a través de la meditación trascendental.

24 BORT GUAL, Iván (2012), Nuevos paradigmas en los telones del relato audiovisual contemporáneo: partículas narrativas de apertura y cierre en las series de televisión dramáticas norteamericanas, Tesis Doctoral, Universitat Jaume I, Castellón de la Plana, p. 105. Y junto a esta serie, otras películas del director, como indica POWER, Dominic (201 1): "Surrealist cinema", en KEMP, Philip (ed.), Cinema. The Whole Story, Londres, p. 75. El guionista, director y productor David Chase, que ve una influencia directa de su formación como pintor en el cromatismo de Twin Peaks, considera que esta serie tiene a la vez un tono muy onírico y "algo de hiperrealista". Véase CHASE, David (2017), "Los sueños del agente Cooper y de Tony Soprano", en CRISÓSTOMO y ROS, Regreso a Twin Peaks, p. 14. En cambio, otros autores ponen en entredicho el supuesto surrealismo de la obra cinematográfica de Lynch, y en cambio la enmarcan en la neofiguración, aunque sí admitan ciertos tintes surrealistas en sus películas y series. Véase PONCE TARRÉ, "Neofiguración e iconoclasia", pp. 303-304.

25 MEMBA, David Lynch, p. 131. En la pintura de Hopper se ha visto "un manifiesto de la idiosincrasia estadounidense y sus estereotipos", plasmando en sus cuadros "las imágenes costumbristas de la América profunda, que oscilan entre la soledad, la alienación y lo superficial". Véase PONCE TARRÉ, "Neofiguración e iconoclasia", p. 284.

26 PONCE TARRÉ, (2018): "Neofiguración e iconoclasia", p. 287.

27 BRADSHAW, "David Lynch: The Art Life review".

28 LYNCH, Atrapa el pez dorado, p. 13. 
La opresión, el desasosiego, lo siniestro que invade la obra pictórica y cinematográfica de Lynch tiene su fundamento en las palabras del propio autor, que evita lo bello y pinta guiado por "el atosigamiento, la asfixia y la claustrofobia. Una opresión en blanco y negro que contiene resultados similares a los de Cabeza borradora" ${ }^{29}$ Esta afirmación tiene su plasmación tanto en su obra plástica como en su cine. La visión del cuerpo humano que ofrece Lynch en su pintura se hace extensiva a sus películas, y en ella ese cuerpo es "un lugar de transformación y de alienación". ${ }^{30}$ Sus pinturas son violentas, espeluznantes e inquietantes. ${ }^{31} \mathrm{Y}$ si el cuerpo humano es lugar de alienación, el hogar es siempre un espacio "trágico y sepulcral donde, no obstante, la vida aflora y araña la superficie del lienzo hasta arrancarle rastros de sangre y superponer esparadrapos". ${ }^{32}$

Hay una evolución en la pintura de Lynch que se pone de manifiesto en el documental, pero no estrictamente en orden cronológico, sino intercalando cuadros, dibujos, fotografías y muebles de diferentes épocas. Lynch vivió una infancia "idílica", pero su arte se muestra inquietante. Cuando los autores insertan planos de obra temprana, se advierte un empleo "hiperminimal" de los colores, como lo define Olson, con pequeños toques o manchas de rojo, dorado o blanco destacándose sobre el fondo oscuro. En cambio, en su pintura reciente el artista dispone áreas de color más grandes y brillantes que, combinadas con fondos terrosos, dan a su obra un aire más cálido y animado. ${ }^{33}$ Esta evolución han querido mostrarla los autores del documental, y se entrecruzan unas obras con las que pinta durante el momento presente, para conseguir contrastes tímbricos, cromáticos pero también anímicos. Por lo tanto, el viaje a través de su arte que se propone en la película no recorre una línea continua, sino que se establece un diálogo -y a veces también una fuerte yuxtaposición- entre su obra de los años sesenta-setenta y la actual. Y la selección que se hace-una amplia muestra

29 La cita completa está recogida en FERRER GARCÍA, Lo siniestro como condición y límite, $\mathrm{p}$. 371.

30 LIM, David Lynch, p. 56.

31 ALM, "The Creative Pathos Of David Lynch".

32 PINTOR IRANZO, "El morador del umbral", p. 224. Este autor define las pinturas de Lynch como negras y expresionistas. Rodríguez señala cómo en sus cuadros, una escenografía precisa y hasta realista alberga figuras distorsionadas, que expresan alguna emoción íntima de angustia o terror imposible de entender para un espectador. Véase RODRÍGUEZ, Hilario J. (2017), "Las partículas elementales. Volverás a Twin Peaks", en CRISÓSTOMO y ROS, Regreso a Twin Peaks, pp. 238-239.

33 OLSON, David Lynch, p. 506. 
entre una producción notable- no es gratuita, ni fortuitas las relaciones que se trazan con su vida a través de ella, pues en esta selección hubo participación directa de Lynch en la elección del material que aparece en pantalla. Las obras mostradas a lo largo del metraje fueron proporcionadas por el propio artista; los directores no insertaron ninguna obra que Lynch no les hubiera facilitado. ${ }^{34}$ Por ello, la evolución que se puede observar en su obra parte del concepto que el propio artista tiene de ella. Las piezas escogidas son significativas para él artísticamente, pero también están relacionadas con momentos de su vida, y arrojan pistas sobre sus intereses. He aquí el acierto de los directores: partir de material muy diverso, pero muy apegado al artista, y montarlo de forma que todo confluyera en la presentación de lo que significaba para él la vida artística.

\section{David Lynch: The Art Life. La génesis del proyecto}

Estrenado en 2017, David Lynch: The Art Life es un documental enfocado en la figura de David Lynch. La película es el resultado del trabajo de un grupo de directores que durante casi cuatro años estuvieron realizando entrevistas al cineasta, centrándose en la primera etapa de su vida, desde su infancia hasta los 31 años, cuando se estrena Eraserhead, su primer largometraje. El director Jon Nguyen reconocía en una entrevista que su intención al hacer el documental era la de comprender al artista que había detrás de las películas de las que se había enamorado, para tratar de entender qué condujo su imaginación. ${ }^{35}$ Para ello, a lo largo del metraje se muestran flashes del viaje emprendido desde su localidad natal, Missoula (Montana), hasta Filadelfia y, finalmente, Los Ángeles, como un contraste claro entre un ambiente feliz en su infancia y un momento más oscuro en la gran ciudad, para volver a la luz de la ciudad californiana. ${ }^{36}$ La película se entiende como un viaje a través de los años de formación del autor, pero también constituye un autorretrato sui generis, tal como la consideraba Young en su crítica para The Hollywood Reporter. ${ }^{37}$

34 Nguyen en entrevista a EWENS, Hannah (2016), "What We Learned About David Lynch After Spending Three Years in His Art Cave", Vice, 05/09/2016 https://www.vice.com/en_us/ article/4w53wn/speaking-to-the-director-of-david-lynch-the-art-life-jon-nguyen (Consultado el 04/05/2018).

35 Entrevista a Jon Nguyen sobre el lanzamiento de David Lynch: The Art Life, Criterion Collection. https://www.youtube.com/watch? v=uwWCu9-516E (Consultado el 27/04/2018). 
Aunque sí es probablemente la película más reconocida de Nguyen, David Lynch: The Art Life no es la primera colaboración de este con Lynch, pues diez años antes habían coincidido en Lynch (one) (2007)..$^{38}$ En esa época, el director de Montana no era partidario de conceder las entrevistas que iban a convertirse en el documental de cuyo estudio nos ocupamos en este artículo. El punto de inflexión en la postura de Lynch se encuentra seis años más adelante, concretamente en 2012. Ese año nacía Lula Boginia, su hija menor, y esta película se entiende, en parte, como un legado de padre a hija, como una memoria privada -aunque hecha pública merced al mismo documental-. De hecho, a Lula está dedicada la película, como se indica al comienzo.

La dirección del documental corrió a cargo de un equipo de tres personas: Jon Nguyen como director principal, Olivia Neergard-Holm como editora y directora -reconocida como tal por Nguyen al finalizar la filmación, por

36 Este contraste aparece reflejado en la obra de Lynch: por contraposición al "paraíso de los jardines con vallas blancas y el reparto del lechero", que conoció en su infancia, se halla el lado oscuro, un aspecto sombrío que late en sus personajes, y que nació durante su estancia en Filadelfia. Véase MEMBA, David Lynch, p. 32. Tras su etapa en Filadelfia, donde había residido durante cinco años, la ciudad angelina le parecía una tierra de promisión. Él mismo reconoce lo afortunado que se sintió de poder vivir bajo esa luz, distinta a la de otros lugares, mucho más brillante que la de Filadelfia. Véase LYNCH, Atrapa el pez dorado, pp. 36-37. Pero esa atmósfera que vivió en Filadelfia tuvo su contrapartida positiva para su expresión artística, pues según Katz pudo nutrir la visión pesadillesca de sus futuras películas. Véase KATZ, The Macmillan International, p. 859. Ros señala que en su cine y obra televisiva, Lynch ha representado algunos avernos urbanos que había conocido bien en su vida adulta, como Los Ángeles y, sobre todo, Filadelfia, escenarios aptos para la irrupción del horror. Véase ROS, Enric (2017), "Los bosques del mal. Visiones del Numen en Twin Peaks", en CRISÓSTOMO y ROS, Regreso a Twin Peaks, p. 127.

37 YOUNG, Deborah (2016), "David Lynch, The Art Life': Venice Review", The Hollywood Reporter, 05/09/2016 https://www.hollywoodreporter.com/review/david-lynch-art-life-venice-925727 (Consultado el 04/05/2018). La cita de Young está reproducida también en HUDSON, David (2016), "Daily | Venice 2016 | David Lynch: The Art Life", Fandor, 08/09/2016 https://www.fandor.com/posts/daily-venice-2016-david-lynch-the-art-life (Consultado el 04/05/2018).

38 En los créditos de este documental, Nguyen figura como productor. Véase https://www.imdb. com/title/tt1032207/fullcredits?ref_=tt_cl_sm\#cast (Consultado el 20/04/2018). Esta obra seguía a Lynch a través del proceso de realización de Inland Empire, antes del estreno de la película en el Festival de Cine de Venecia. Véase EWENS, Hannah (2016), "What We Learned About David Lynch After Spending Three Years in His Art Cave", Vice, 05/09/2016 https://www.vice.com/en_us/article/4w53wn/speaking-to-the-director-of-david-lynch-the-artlife-jon-nguyen (Consultado el 04/05/2018). 
todo lo que había contribuido a la misma-, y finalmente Rick Barnes como un "alias" fundamental que hizo posible el proyecto. ${ }^{39}$ Junto a ellos, cabe señalar que el resto del equipo estaba compuesto por auténticos fans de la obra de Lynch. Esto hizo posible el entusiasmo con que se llevó a cabo la filmación, auténtica oda a la figura del polifacético artista. Nguyen ya había pasado una larga temporada rodando para Lynch (one) durante el proceso de rodaje de Inland Empire, con lo que conocía bien al director y su forma de trabajar. Los productores del documental fueron Nguyen, Jason S. y Sabrina Sutherland, a los que se sumaron otros coproductores como Marina Girard-Muttelet. ${ }^{40}$ Por su parte, el propio Jason S. se encargó de la dirección de fotografía, con un trabajo que Young tilda de lynchiano, adjetivo que Halligan emplea para referirse también al documental en su conjunto. ${ }^{41}$ Finalmente, la música, que juega un papel relevante, está firmada por Jonatan Bengta. ${ }^{42}$ Pero fundamentalmente, en la película suena música del propio David Lynch. ${ }^{43}$ La música empleada en la película sigue la idea expresada por Lynch de la necesidad de casar con la imagen y realzarla, de tal manera que "el resultado es mayor que la suma de las partes". ${ }^{44}$ Además, esa utilización del sintetizador para crear un ambiente desasosegante, que tanto gusta a lynch y que tan bien supo interpretar su compositor preferido, Angelo Badalamenti, tiene su eco en la película que nos ocupa. ${ }^{45}$

39 ANDERSON, Ariston (2017), "Jon Nguyen on David Lynch: The Art Life, How Twin Peaks Delayed Production and the Downside of Kickstarter", Filmmaker Magazine, 17/04/2017 https:// filmmakermagazine.com/102444-jon-nguyen-on-david-lynch-the-art-life-how-twin-peaks-delayedproduction-and-the-downside-of-kickstarter/\#.W+OMM4jwaUk ( Consultado el 15/05/2017).

40 https://www.imdb.com/title/H1691152/fullcredits?ref_=tt_cl_sm\#cast (Consultado el 04/05/2018). Jason S. también había participado en Lynch (one), y Sabrina Sutherland en la producción de Inland Empire y la tercera temporada de Twin Peaks.

41 YOUNG, "'David Lynch, The Art Life': Venice Review", y HALLIGAN, Fionnuala (2016), "'David Lynch: The Art Life': Venice Review". Screen Daily, 04/09/2016 https://www.screendaily.com/reviews/david-lynch-the-art-life-venice-review/5108847.article (Consultado el 06/05/2018).

42 Asimismo, hay música adicional de Josef Maria Schäfers, Stella Luncke, Olga Blinky Luncke, Clayton Thomas y Bernd Öszevim.

43 LIVINGSTONE, "The Organic, Violent Comedies of a Young David Lynch". Concretamente, de David Lynch suenan tres piezas, interpretadas por él mismo y por Dean Hurley: I Have a Radio, The Night Bell With Lightning y Sparkle Lounge Blues, las tres pertenecientes al álbum Crazy Clown Time (2011). La primera de ellas apareció como bonus track en la edición japonesa del álbum.

44 LYNCH, Atrapa el pez dorado, p. 45.

45 Sobre el uso de este recurso en otras películas de Lynch, véase CARMONA, Música \& Cine, p. 30. 
A la hora de plantearse el documental, la idea de Nguyen era la de ofrecer un retrato más amplio y revelador de la vida de David Lynch que el efectuado en su primera colaboración. ${ }^{46} \mathrm{El}$ proyecto tardaría en realizarse, puesto que Lynch se encontraba preparando la tercera temporada de Twin Peaks y durante varios meses no tuvieron acceso al director. ${ }^{47}$ Pero a partir de ese momento, y durante casi tres años, los autores grabaron más de veinte conversaciones de audio en la casa de Lynch, para lo que dispusieron de los fines de semana. ${ }^{48}$ En una acertada decisión, los autores optaron porque fuese el propio cineasta de Montana, a través de estas grabaciones, quien narrase sus primeras tres décadas de vida. A pesar de haber entrevistado también a varios de sus amigos, los autores prefirieron dejar hablar en la película solo a Lynch, para que su historia no fuese distorsionada con otras voces ${ }^{49} \mathrm{El}$ material reunido durante todas las sesiones de entrevistas superaba las 30 horas de grabación. Esto supuso, en palabras de Neergard-Holm, una auténtica tortura para extraer los fragmentos que tendrían cabida en el documental..$^{50}$ La producción corrió a cargo de las compañías Absurda, Duck Diver Films, Hideout Films y Kong Gulerod Film. El proyecto pudo salir a la luz gracias al apoyo económico de muchas personas vía crowfunding. La mitad de los fondos se pudo conseguir a través de la plataforma de financiación Kickstarter, y la otra mitad gracias a varias personas implicadas en el proyecto ${ }^{51}$.

Los directores consideran esta película como un retrato íntimo de la infancia y años de formación de Lynch. Es una obra más madura que Lynch (one), propia de quien ha evolucionado durante una década hacia unas cotas más altas de sofisticación a diversos niveles concretamente, Nguyen, que había participado como productor de la anterior-. Pero ello supuso alguna

46 ANDERSON, "Jon Nguyen on David Lynch".

47 ANDERSON, "Jon Nguyen on David Lynch". De hecho, según indica Nguyen en una entrevista concedida a Ewens, los momentos en que Lynch aparece escribiendo en el documental corresponden a la escritura de Twin Peaks. Véase EWENS, "What We Learned About David Lynch".

$48 \mathrm{http}: / /$ www.yelmocines.es/content/pdf/extended-synopsis/DAVID_LYNCH_THE_ART_LIFE. pdf (Consultado el 14/04/2018), y EWENS, "What We Learned About David Lynch".

49 ANDERSON, "Jon Nguyen on David Lynch".

50 MONTPELIER, Rachel (2016), "LFF 2016 Women Directors: Meet Olivia Neergaard-Holm - "David Lynch: The Art Life", Women and Hollywood, 14/10/2016 https://blog.womenandhollywood.com/lff-2016-women-directors-meet-olivia-neergaard-holm-david-lynch-the-art-lifec5635b5890ae (Consultado el 15/04/2018).

51 ANDERSON, "Jon Nguyen on David Lynch". 
crítica negativa de quienes veían en The Art Life muchas similitudes con su predecesora, lo que supuestamente le restaba frescura y capacidad de sorpresa. ${ }^{52}$ Más bien, consideramos que los autores $-y$ fundamentalmente Nguyen- quisieron trabajar sobre las bases que tan buenos frutos habían dado previamente, y desarrollar una obra más compleja, que hiciera verdadera justicia a la figura de Lynch, sobre todo como artista plástico, y que permitiera al público -como indica Alm-acceder a la psique del cineasta. ${ }^{53}$

\section{Análisis e interpretación de la película}

Estructuramos el análisis de la película teniendo en cuenta los distintos componentes: el material mostrado en el documental, la forma de montarlo y la interpretación de episodios significativos para lynch, así como los escenarios y encuadres escogidos.

\subsection{Los materiales utilizados}

Según Olivia Neergard-Holm, este documental es "una memoria visceralmente personal que usa su propia narración [de Lynch], obras de arte, vídeos y fotos para arrojar luz sobre las experiencias que lo ayudaron a formarlo como un artista y cineasta inflexible" ${ }^{54}$ Para mostrar esa memoria personal de la que habla la codirectora, se valieron de ese material tan diverso y a la vez tan íntimamente ligado a su figura. Hay una frase de David Lynch que ayuda a entender la forma en que se ha construido el relato, y el porqué de esa mezcla heterogénea de imágenes -fotografías, pinturas, vídeos- traídas a colación durante el metraje: "Creo que cada vez que haces algo, como una pintura, traes cosas del pasado, puedes conjurar esas ideas y colorearlas, aunque sean nuevas ideas, el pasado las colorea" ${ }^{55}$ Lo que vemos, entonces, es el acto de pintar de un director que, a través de esta actividad, además de crear, está conjurando el pasado, y

52 Por ejemplo, MEDINA, Marta (2017), "'David Lynch: The Art Life', los orígenes de un cineasta inimitable", El Confidencial, 31/03/2017 https://www.elconfidencial.com/cultura/cine/201703-31/david-lynch-the-art-life-documental_13581 14/(Consultado el 21/04/2018).

53 ALM, "The Creative Pathos Of David Lynch In 'The Art Life"." Forbes, $31 / 03 / 2017$ (en línea). https://www.forbes.com/sites/davidalm/2017/03/31/the-creative-pathos-of-david-lynch-inthe-art-life/\#385d03296ac0

(Consultado el 13/05/2018).

54 MONTPELIER, "LFF 2016 Women Directors".

55 Citado en http://www.yelmocines.es/content/pdf/extended-synopsis/DAVID_LYNCH_THE_ ART_LIFE.pdf (Consultado el 14/04/2018). 
eso nos da pie a ir relacionando pasado y presente, a reinterpretar desde la óptica del cineasta maduro sus años de formación como pintor, y cómo desembocó en el cine.

El documental utiliza, pues, material de muy diversa procedencia y características, aunque vinculado a la persona de David Lynch. Todo lo que aparece en el documental tiene relación directa con él. Pero hay una decisión de los autores que hace que no se limite a una simple acumulación de imágenes sobre Lynch: el propio montaje del documental se vale de la imagen, del sonido ambiental y de la música incidental para transmitir de forma más eficaz y a la vez sutil ciertos estados de ánimo, sus inquietudes, sus sentimientos hacia su entorno y hacia el mundo del arte $y$, finalmente, hacia el cine. Así, el director aparece pintando, y se muestra al espectador una selección de cuadros suyos y fotos familiares. A lo largo de los $85 \mathrm{mi}$ nutos de película, el artista pinta con las manos y con pincel. Las fotografías conectan con la historia que cuenta, y las composiciones y fotomontajes también. En la película se muestra, fundamentalmente, una selección de la producción pictórica y fotográfica de Lynch realizada durante los últimos 15 años, pero también obra de juventud. En este sentido, destacan Sin título (1968) o Fish Kit (1980), esta última perteneciente a una época en la que ya se había estrenado como director cinematográfico. Entre las fotografías, sobresalen las pertenecientes a las series Small Stories (2013) y Woman Thinking (2008).

Para introducir a ciertos personajes, los autores se valen de vídeos domésticos y fotografías, así como de pinturas y dibujos del artista. El de emplear obra gráfica de Lynch es un recurso que se utiliza en varias ocasiones a lo largo del metraje. Entre ellas, cuando aborda su viaje a Salzburgo con la intención de estudiar con Oskar Kokoschka, para lo que se acompaña de su amigo Jack Fisk, aunque desafortunadamente el pintor no se encontraba allí, y vuelven a los quince días. ${ }^{56} \mathrm{Al}$ tratar este episodio, vemos la obra Two Friends, y seguidamente una fotografía de la pareja de los jóvenes amigos sonrientes. A Fisk lo volverán a mostrar trabajando en otras fotografías. Luego, cuando rememora su periodo en la Academia de Bellas Artes en Filadelfia, va apareciendo ante los ojos del espectador obra gráfica donde presenta sus impresiones acerca de sus vecinas, a las que apreciaba poco - a una la considera como una racista que apestaba a orín, y a

56 LIVINGSTONE, "The Organic, Violent Comedies of a Young David Lynch". Fisk sería, años después, el diseñador de producción de Cabeza borradora y Mulholland Drive. Véase MEMBA, David Lynch, p. 24. 
otra como una loca-. ${ }^{57}$ Este fragmento está enmarcado por una escena del anciano artista trabajando en una pintura, en la que está retirando materia de la superficie del lienzo con una cierta virulencia, y reforzando así la sensación de malestar que había vivido en aquellos momentos. Antes se han mostrado varias fotografías de la ciudad tomada por otro de los alumnos de la Academia de Bellas Artes, Will Brown, que sirven para contextualizar el ambiente en que se desenvolvió el joven artista.

\subsection{El montaje: ritmo y selección de las piezas}

Si bien el film comienza de una manera relativamente convencional, con la infancia de Lynch narrada por él mismo, desde el minuto 5, con el traslado de la familia desde Montana a Idaho se produce un giro hacia lo que Alm considera como "un espacio peculiar a la vez familiar y perturbado" ${ }^{58}$ Este será el tono que predomine en el resto del metraje. Resulta de gran interés el modo en que los autores del documental van reflejando la íntima unión entre la vida de Lynch y su arte. Mientras el narrador va rememorando momentos y personas que dejaron huella en su vida, se muestran en pantalla obras pintadas por el autor en esas épocas, intercalándolas con otras que realiza en el presente -durante el periodo de entrevistas-. Todo está perfectamente controlado en el montaje final: no solo las piezas seleccionadas en cada momento, sino también el ritmo al que van apareciendo ante los ojos del espectador. El ritmo que los directores imprimen a la película, que va en algunas secuencias del reposo a la sucesión frenética de planos de su obra pictórica y gráfica, es uno de los valores del documental. De los cientos de pinturas y dibujos seleccionados, muchos aparecen como meros flashes ante los ojos de un espectador bombardeado con imágenes muy agresivas, mientras que otras merecen un tratamiento en que la cámara se demora con "amoroso detalle", tal como indica Huddlestone. ${ }^{59}$ Por ejemplo, al tratar sobre su periodo en Virginia -a partir del minuto 14:20-, que le parecía siempre de noche por contraposición con la soleada Boise, se sucede una rápida acumulación de obra sobre papel. Tras las imágenes que muestran al Lynch adolescente con sus hermanos, vestido de boy scout, empieza una rapidísima sucesión de pinturas y acuarelas, sobre todo en blanco y negro, con leves y duras notas de color: Head, Head Talking about Billy, Man with flies, Head and Body-que aparece en pantalla cuan-

57 Entre otras obras, aparece Sleep.

58 ALM, "The Creative Pathos Of David Lynch".

59 HUDDLESTONE, Tom (2016), "David Lynch: The Art Life", Time Out, 04/09/2016 https:// www.timeout.com/london/film/david-lynch-the-art-life (Consultado el 07/05/2018). 
do trata sobre los espasmos en los intestinos que sufrió en esa época, y que representa a una figura humana con el cordón umbilical unido a un gran estómago-, Hello gooodbye, Smoking -mostrada al referir su afición a fumar tabaco-, I see myself-recordando sus viajes a Washington para beber-, Arms -que aparece cuando refiere sus escapadas de casa por las noches-, There is nothing here, please go away (2012), tras la que se muestra, por corte seco, obra gráfica a ritmo acelerado, apoyándose el montaje en la música. Por fin se detiene en $\mathrm{Help}$ me, que representa a un niño de facciones grotescas con una gran boca roja, de la que se aleja la cámara mediante un zoom out. Así, a través del montaje y la selección de obras de Lynch, se presenta a un joven perdido, que está sufriendo y que necesita ayuda.

Este fragmento se entiende en toda su dimensión si se relaciona con el anterior, en que Lynch empieza a recordar la historia del señor Smith y no puede terminarla. La noche antes de partir de Boise rumbo a Virginia, la familia se despedía de los vecinos, entre ellos el señor Smith. Nguyen reconocía que este episodio fue el único para el que no obtuvieron una respuesta concluyente: Lynch niño abandonando Montana y diciendo adiós al Sr. Smith, al que no conocía. ${ }^{60}$ Es una historia cuyo recuerdo afecta mucho al director. Nguyen piensa que debe simbolizar el fin de sus años felices y el paso a una época más oscura en que se establecieron sus ansiedades -las que se muestran a través de sus pinturas en el fragmento que hemos analizado antes-. Como ilustración de este episodio, aparece la acuarela Tree and home (2009-2010, minuto 12:40). A continuación, se pasa a un plano general de Lynch sentado en el taller de carpintería de su casa, dibujando y fumando a la vez. En ese mismo plano pasa a hablar de dos amigos de su juventud que no le convenían. Entonces, el tono pasa a ser más sombrío, premonitorio de lo que vendría luego, pero la imagen que hemos visto carece de la crudeza de las pinturas que aparecen después.

\subsection{La narración de episodios significativos}

A lo largo del documental, hay algunos episodios de la vida de Lynch que éste recuerda como especialmente notables para su evolución. Entre ellos, el episodio de sus visitas a la morgue, que ya señalamos como una influencia importante en su obra, en el que destaca el modo en que los autores del documental han relacionado la producción plástica de Lynch y el relato 
de su vida. Estas visitas se produjeron a raíz del encuentro nocturno en una cafetería del artista con un empleado del turno de noche de la morgue. En el momento en que el cineasta de Missoula rememora su invitación a asistir a la morgue, aparece la pintura This man was shot 0.9502 seconds ago (2004; minuto 54:20, impresión a chorro, tinta y técnica mixta), cuyo escenario corresponde a la descripción del edificio que recuerda. ${ }^{61}$ Los autores muestran diversos planos de detalle de la obra. La cámara se va moviendo por la superficie de la pintura, y luego se muestra la obra completa. La visita a la morgue suponía para el joven Lynch una oportunidad para imaginar historias, para elucubrar acerca de cómo esas personas acabaron allí. En este momento, los autores optan por incluir una multiplicidad de planos de corta duración, en los que se muestran otras obras trabajadas por Lynch y también dotadas de una gran riqueza matérica, figurativas y violentas -como el personaje del cuadro antes mencionado, que contrasta con las lisas superficies del fondo de la pintura-. Se insinúa visualmente que estas obras son -al menos en parte- la consecuencia de esas visitas a la morgue, que le abrieron un mundo vedado a otros.

La habitual inclusión de palabras y frases en la obra pictórica de Lynch permite a los autores del documental puntualizar y enriquecer aquello que Lynch narra. Esta información escrita se emplea en el documental como un adecuado recurso narrativo y expresivo. En ocasiones, las palabras sueltas o frases que pueblan sus lienzos no tienen especial incidencia en el relato, pero a veces su utilización se hace con una sincronización total con la narración de Lynch. Por ejemplo, merece destacarse el momento ya aludido antes en que el cineasta de Missoula recuerda que siempre estaba fumando cigarrillos, y se muestra su obra Smoking (2008), en la que una cara grotesca fuma un cigarrillo del que parece salir una llamarada de fuego. Finaliza esta secuencia con la obra Help me, en la que una cara rechoncha parece gritar auxilio, como lo estaba pidiendo el Lynch adolescente. Asimismo, la música, llena de estridencias y disonancias en los momentos más duros de su periplo vital, contribuye a crear una atmósfera de opresión y de angustia.

La misma decisión adoptan los autores del documental en el siguiente fragmento, en el que el futuro cineasta rememora una época problemática en la que frecuentaba malas compañías. En este periodo, su madre -a la

61 Aunque él señala que el personaje al que han disparado se encuentra en el recibidor de un banco, para lo que ha mezclado pintura y fotografía. 
que apreciaba profundamente- se mostraba decepcionada con él por no encontrar el potencial que creía que tenía, y que había visto en su infancia (minuto 17)-. Era este un momento de su vida en que no estudiaba, y en que empezaba a tener otros intereses, que él mismo especifica: bailar agarrados en las fiestas, conocerse, enamorarse. Esta época va subrayada en el metraje por una selección de obras en blanco y negro que ejemplifican estos intereses: Man and woman meet at night (2009) -un encuentro agresivo entre dos figuras sin rostro-, Girl dancing (2008), I Hold you tight (2009) -en referencia al enamoramiento, en este caso representado por dos figuras, ella desnuda, y él agarrándole del cuello, con unos brazos muy largos y caras de horror-, y A Parting Kiss (2007) ${ }^{62}$-un beso nada sensual, sino grotesco-.

Otro episodio especialmente relevante para comprender el modo en que el montaje hace uso de obra gráfica de Lynch para apoyar el relato de su vida es el que narra una fuerte discusión mantenida con su padre, porque el joven pretendía volver a casa más tarde de las 11 de la noche entre semana y no le dejaban. ${ }^{63}$ El desencuentro terminó gracias a la intercesión de Bushnell Keeler, el profesor de pintura de Lynch. ${ }^{64}$ Tras las explicaciones de Keeler, el joven pudo volver a casa a la hora que quisiera y todo fue bien. El montaje de esta secuencia ofrece una sucesión de planos de detalle de obras fuertemente impregnadas de violencia y agresividad, en consonancia con los sentimientos generados en el joven aspirante a artista. La forma de combinar la obra de Lynch con el relato de un momento de cambio en su vida, de cierta convulsión, es todo un acierto. Para ello, los directores se valen de las tensiones generadas a través de la música, pero también de la gama cromática predominante en las pinturas y dibujos seleccionados. De esta manera, los colores que prevalecen en este segmento son el rojo y el negro, destacando la presencia de líneas negras que otorgan crudeza al relato de los hechos. ${ }^{65}$ Pero cuando intercede Keeler, vuelve a mostrarse al

62 Estas y otras obras formaron parte de la exposición Man Waking From Dream, celebrada en el FRAC Auvergne entre enero y mayo de 2012. Véase el catálogo de la misma en VERGNE, Jean-Charles et al. (2012), Man Waking From Dream, Clermont Ferrand.

63 La secuencia comienza en el minuto $28: 28$ con un plano desenfocado que se enfoca y muestra al protagonista de perfil, pintando un cuadro que no llegamos a ver en este momento, pero que tendrá un significado al final de la misma.

64 Su padre llegó a decir a David que ya no formaba parte de su familia, por lo que el adolescente se sintió desolado. Bushnell Keeler llamó a su padre, y le explicó que hijo iba a pintar allí todos los días, no a perder el tiempo, y que se tomaba la pintura muy en serio.

65 Entre ellas, Many degrees of freedom y Oh My thoughts they are so mixed up and funny (2013). 
Lynch actual dando unas pinceladas de tono celeste claro, fragmento que devuelve la calma al relato, siquiera momentáneamente. Estas pinceladas de azul intenso sobre un lienzo tonos ocres, unidas a una música incidental de carácter más sereno, contribuyen a diluir la tensión generada en los instantes previos. Eso da pie al cineasta a hablar de su padre en términos cariñosos, para lo que los autores se apoyan en diversos vídeos caseros y fotos antiguas. ${ }^{66}$ En este momento (minuto $31: 10$ ) se muestra al anciano Lynch con su hija Lula. Por lo tanto, el David Lynch hijo, ese joven enfrentado a su padre por los horarios de llegada a casa, se va a convertir en un padre paciente y hogareño, que aparece dibujando junto a su hija pequeña en lo que Livingstone considera una yuxtaposición un tanto extraña. ${ }^{67}$

Un momento significativo de la vida del Lynch estudiante es el de la radio, que él recuerda con interés. Cuando se trasladó a Boston, dos días antes de entrar en la Academia, se encerró en su casa a escuchar la radio, no saliendo de casa y no levantándose salvo para comer e ir al baño. Para mostrar su falta total de interés en salir al exterior, aparecen varias litografías que representan insectos en interiores domésticos, entre ellas Insect on chair (2007). Como colofón a esta historia, aparece la pintura I have a radio, realizada durante la época en que se rodó el documental, según demuestra su intervención en ella. Por lo tanto, se refuerza el carácter autobiográfico de la obra de Lynch, aunque no fuera realizada en el momento en que sucedió. Parece que estas obras conjuran el pasado. La relación temática con los episodios que rememora es muy clara en este caso. Otras piezas trabajadas en época reciente remiten -si no estrictamente por la temática abordada en ese instante, sí por textura o por algún otro detalle relacionado con la narración- a un momento concreto de su pasado. Lo hace al comienzo del documental, cuando lo vemos trabajar, tras los títulos

66 La relación de Lynch con su padre es abordada también en otro momento de la película, cuando explica su afición a construir cosas juntos, que le divertía mucho. Como muestra aparece una veleta realizada en esa época, y después se presenta la obra FISH KIT (1980). Este fue el primer kit que realizó Lynch, y lo hizo en Inglaterra durante la postproducción de The elephant Man. Consta de un pez diseccionado que ha dispuesto sobre un papel, anotando en él instrucciones para ensamblarlo como si de un modelo de avión se tratara, y fotografiándolo a continuación. Véase COZZOLINO, David Lynch, pp. 147-148.

67 LIVINGSTONE, "The Organic, Violent Comedies of a Young David Lynch". Sobre todo se refiere a estos planos con su hija pequeña cuando recuerda su primer matrimonio de manera ambivalente. En esta escena, se aprecia al fondo una reproducción de El jardín de las delicias de El Bosco que el cineasta tiene en su estudio. No por casualidad, ha habido autores que han visto una similitud entre la manera de filmar el paisaje en Twin Peaks o Terciopelo azul y la "belleza extraterrestre de la obra de El Bosco". Véase ROS, "Los bosques del mal", p. 127. 
de crédito iniciales, en una pintura que va a aparecer a lo largo del metraje. En esta ocasión está extendiendo una masa blanca sobre el lienzo, cuando rememora sus primeros juegos con un amigo, con quien gustaba de jugar con el barro. La forma de aplicar el pigmento ahora recuerda a esos momentos de la infancia.

Asimismo, Lynch recuerda un acontecimiento trascendental para su devenir artístico: el momento en que, pintando un jardín con plantas, el cuadro parece moverse agitado por el viento que silba. Se encontraba en ese momento en su cubículo dentro de una gran sala de la Academia de Bellas Artes de Pensilvania, con el cuadro a medio pintar: un jardín de noche, oscuro, con plantas verdes que emergían de la oscuridad..$^{68}$ Es el cuadro que supuso para él una epifanía, una auténtica revelación: la de conseguir la pintura en movimiento. Siente como si un viento saliera del lienzo y agitara las hojas pintadas: "¿ $\dot{\partial}$ si las pinturas se movieran? $\dot{\partial} Y$ si tuvieran sonido?". ${ }^{69} \mathrm{He}$ ahí la gran idea, el paso necesario hacia el cine, que plasma en su corto Six men getting sick (1967). El humo le sirve para introducir el recuerdo. Y se muestran en pantalla animaciones de plantas moviéndose sobre fondo negro, para recrear los recuerdos del cineasta.

En relación a la utilización de palabras y frases en la obra pictórica del artista para enlazar con el relato de su vida, queremos destacar dos obras que aparecen en diferentes momentos del metraje. En primer lugar, Things $I$ learned in school, que realiza en el presente (Fig. 2). ${ }^{70} \mathrm{~A}$ lo largo del metraje se ha ido mostrando cómo realiza las palabras en alambre y plastilina, y cómo las ubica en la zona superior de la pintura. La presentación de esta obra sirve a los directores para introducir los recuerdos de la fase escolar. En el minuto 32:10 aplica la frase al lienzo. En este momento habla de los amigos del colegio, que no eran esas malas amistades que lo habían llevado a tener problemas. Lynch reconoce llevar en este momento de su vida tres vidas a la vez: su vida familiar, el estudio y los amigos. Ahora frota con esponja sobre la zona inferior del lienzo, que está tumbado. Con las manos va esparciendo un líquido abajo. Pero más adelante vuelve a aparecer la obra, para contraponerla a la sensación de pérdida de tiempo en su perio-

68 LYNCH, Atrapa el pez dorado, p. 23.

69 LIM, David Lynch, p. 12.

70 Esta pieza formaría parte de la reciente exposición Silence and Dynamism, celebrada en Torun (Polonia), entre noviembre de 2017 y febrero de 2018. 
do en la Escuela en Boston, cuyas clases -a excepción de la de esculturaodiaba, pues le obligaban a hacer ejercicios de un modo concreto -justo lo contrario que alababa de su madre cuando era niño-. Eso lo animó a emprender el fallido viaje de estudios con Jack Fisk a Europa. Vuelve a esta obra cuando aborda una visita de su padre en 1967, en su época en la Academia. Lo vemos trabajando con espuma, que impregna de pegamento y algodón y luego pinta y dispone sobre el lienzo -es el vómito que sale de la boca del protagonista del cuadro-. El fragmento está muy bien elegido, pues Lynch habla de su fascinación por las texturas, por sus experimentos sobre la descomposición de la fruta, de pájaros muertos, de un ratón plastificado, etc., que llevaron a su horrorizado padre a sugerirle que no tuviera hijos. ${ }^{71}$ El propio Lynch ha reflexionado en un ensayo sobre el proceso de construcción y destrucción en la obra de arte, de cómo juntar materiales difíciles provoca una reacción orgánica, de la acción y reacción. ${ }^{72}$ Esta forma de concebir la creación artística se refleja directamente en su arte, y el documental ofrece un testimonio de ello en los fragmentos correspondientes al trabajo actual del artista.

Junto a ella, destaca la pintura en tonos ocres y celeste que Lynch trabaja en el presente del documental. Esta obra aparece recurrentemente asociada a momentos positivos del relato de su vida. Igual que había sucedido con la discusión con su padre, vuelve a mostrarse el lienzo cuando narra la llamada que había recibido para comunicarle que había ganado la beca

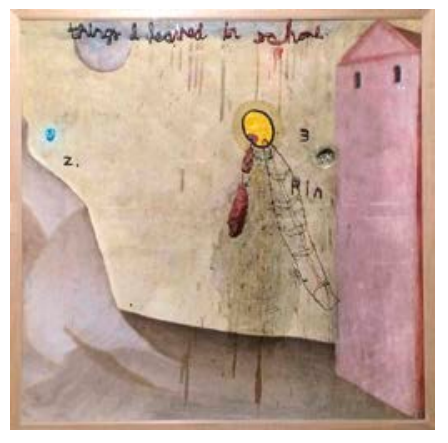

Fig.- 2. David Lynch: Things I learned in school (Foto: www.facebook.com/Lychland) ${ }^{73}$

71 Ironías de la vida, pues justo en ese momento, sin él saberlo, su novia estaba embarazada de su hija Jennifer.

72 LYNCH, Atrapa el pez dorado, p. 22.

73 https://www.facebook.com/Lynchland/photos/things-i-learned-in-schooldavid-lynch-is-seenworking-on-that-big-painting-in-ma/1731139323618954/ (Consultado el 13/05/2018). 
para el Instituto Americano de Cine, y se le ve sonriendo. En ese instante, el anciano artista perfila la línea de separación entre la parte superior celeste y el resto ocre. La selección de este momento para contar su aventura en el Instituto Americano de Cine no es una mera casualidad, pues establece una suerte de línea divisoria en su vida: una línea hacia una época más positiva, tras una llamada que le cambió la vida, como él mismo reconoce. Precisamente estos recuerdos vienen precedidos de unos planos que presentan al autor trabajando en una mesa, sobre la que aparecen pintados los nombres de la actual familia de Lynch ("Mommy", "Daddy" y "Lula", minuto 1:19:00).

\subsection{Lynch en el estudio-confesionario-cárcel: los encuadres es- cogidos}

Un aspecto que se ha cuidado especialmente en este documental, y que responde a los intereses de los autores, es el relativo a los encuadres de los planos en los que aparece hablando, pintando o fumando el autor. Esta película, realizada desde una posición de altura física como son las colinas de Hollywood (tan lynchianas, por lo demás, como muestra Mulholland Drive), aprovecha las mismas para mostrar algunos planos panorámicos del paraje en que se halla la residencia del artista, con un sol que entronca con su visión límpida y brillante del cielo de Los Ángeles. El protagonista absoluto del documental aparece en el patio de su casa, en su estudio cubierto, - bien en el estudio de grabación. En los dos primeros casos domina la iluminación natural, y artificial en el tercero, con contrastes de claroscuro evidentes. Dos instalaciones -como él las llama- amplias, y otra pequeña, con una tenue iluminación. El documental comienza con un plano de Lynch sentado en un patio de su casa, fumando tranquilamente, y mirando hacia la derecha del encuadre. Se muestra un contraplano de una pintura suya (The story of the ANGEL of totality, 2009), con una figura blanca en huecorrelieve sobre un límpido fondo azul. ${ }^{74}$ Es relevante que se haya elegido esta obra como la primera del sinnúmero de las escogidas entre su vasta producción, por su simbología y su cromatismo. Se nos muestra al artista maduro mirando hacia una imagen pacífica y simbólica: en la actualidad se encuentra en un momento de paz, de equilibrio, de plenitud. Pero las siguientes obras en presentarse al espectador ya son de un aspecto más duro, entre ellas Do you want to know what I really think? (2003), que

74 Esta pintura figuró en la exposición Silence and Dynamism en Torun (Polonia). 
muestra a un hombre con gafas mirando hacia la derecha, repitiendo la posición de Lynch en el plano anterior. Esta pintura, realizada en técnica mixta e impresión a chorro, tiene unas texturas que resultan propias del quehacer pictórico del artista, sucia y violenta. ${ }^{75}$ Cuando baja a su estudio de grabación, que parece una cárcel, se sienta y fuma -lo hace mucho a lo largo del documental-. Pero la voz que escuchamos es en off: él sigue fumando. Es entonces cuando aparecen los títulos de crédito.

Otro encuadre que merece destacarse es el elegido para introducir el recuerdo de sus vecinas de Filadelfia. En este momento, Lynch parece hablar al espectador desde lo que semeja un confesionario o, incluso, una cárcel -por la presencia amenazadora de los barrotes- (minuto 49). Es su estudio de grabación, que se encuadra en picado para favorecer esa sensación de opresión, de falta de libertad, que se mitiga en los encuadres laterales de la misma habitación, con uno de los cuales se cierra la película antes de dar paso al poema final. Cuando rememora a sus vecinas de Filadelfia, los autores presentan una muestra de fotografías en blanco y negro: un pasillo, chimeneas, una pared desconchada, un cristal con gotas de agua, fábricas, un animal muerto, etc. Es decir, se están exhibiendo algunas de las texturas ricas y diversas que Lynch trabaja en su pintura. La misma sensación de confesionario tiene un fragmento anterior (minuto 40:40), en el recuerda haber fumado hierba en una ocasión en que fue a un local donde tocaba Bob Dylan.

El humo de los cigarrillos va a tener un papel relevante (Fig. 3). Está presente durante el documental, pues vemos al cineasta fumando en buena parte de las secuencias. Como hemos indicado antes, el humo sirve para introducir recuerdos. Con él se abre la película, y con él se cierra. En el momento en que rememora su decisión de dedicarse a la pintura (minuto 21), no por casualidad, la pantalla se inunda literalmente de humo.

\section{Conclusiones}

David Lynch: The Art life es un documental fundamental para acercarse a la producción pictórica de David Lynch, y a su periplo vital hasta desembarcar en el cine. A pesar de estar concebido como memoria transmitida por el artista a su hija menor, y de centrarse en sus primeras décadas de vida, esta película ahonda en la personalidad y gustos del futuro cineasta, apor-

75 De hecho, a lo que mira el hombre es a una mujer semidesnuda, a la que apunta con un cuchillo. Y junto a esta, otras del mismo estilo como Wajunga Red Dog (2005, impresión a chorro, tinta y técnica mixta). 
tando pistas sobre sus inquietudes, intereses y claves de su cine. Para ello, los directores dan el protagonismo absoluto a Lynch, narrador y a la vez objeto del film. La pintura juega aquí un papel primordial, pues se muestra mucha obra del artista, pero también a él pintando, y los directores juegan con este material a niveles semánticos. El ritmo con que aparecen, los movimientos (o no) de cámara, la música que acompaña y subraya, etc., son elementos que configuran una obra única, en la que a través de estas piezas se muestra lo siniestro, lo extraño, etc., que es marca de la casa del cine de Lynch. Entre las bondades de este documental, Costa destaca su condición de síntesis magistral del quehacer de Lynch en sus primeros años, pero a la vez su capacidad de aportar pistas para entender "los orígenes experienciales de algunas de sus imágenes más perturbadoras", así como su ética del trabajo y "su capacidad para mirar el mundo desde ese ángulo privilegiado que libera el inconsciente de lo real". ${ }^{76}$ Asimismo, hay autores que consideran este documental en cierto sentido como una concreción audiovisual de Atrapa el pez dorado, el imprescindible libro del Lynch sobre su obra y su filosofía. ${ }^{77}$

A pesar del fuerte carácter autobiográfico del documental, algunos autores echaron de menos una mayor exploración de elementos propios del cine de Lynch. ${ }^{78}$ Nosotros consideramos que ese universo sí está incluido, aunque de forma sutil. En primer lugar, el documental se preocupa por mostrar indicios de aquello que conocemos como "lynchiano": lo vago, unido a nociones inefables -lo sublime, lo misterioso, lo miserable-, "y a las fuertes sensaciones que caracterizan lo mejor de Lynch: el terror abismal, la belleza dolorosa, la tristeza convulsiva", en palabras de Lim. ${ }^{79} \mathrm{O}$, como indica

76 COSTA, "Oscuridad y esplendor".

77 MEDINA, "'David Lynch: The Art Life"".

78 Medina considera que, a pesar de sus valores, "falta una mayor incorporación al filme de ese universo tan propio, tan intrigante y tan inigualable como el de Lynch, cuya influencia en la cultura contemporánea ha sido tal que hasta cuenta con su propio adjetivo". Véase MEDINA, "'David Lynch: The Art Life'". No fue esta la única crítica negativa al documental. Algún otro crítico lamentó que esta película se centrase en el arte y no en la vida de Lynch, por lo que, aunque era informativo hasta cierto punto, daba la sensación de que algo faltaba: que hay más en Lynch que lo que la película se preocupa por explorar. Véase EVANGELISTA, Chris (2016), "Documentary 'David Lynch: The Art Life' Tells The Origin Story Of The Director [Venice Review]", The Playlist, 05/09/2016 https://theplaylist.net/documentary-david-lynch-art-life-tells-origin-story-director-venice-review-20160905/ (Consultado el 06/05/2018). Estas críticas proceden de quien probablemente no ha entendido que, para Lynch, su vida era su arte, como él mismo aclara en el documental y en Atrapa el pez dorado, y que centrarse en su arte era la mejor manera de enseñar al público cómo concibe la vida este autor.

79 LIM, David Lynch, p. 19. 


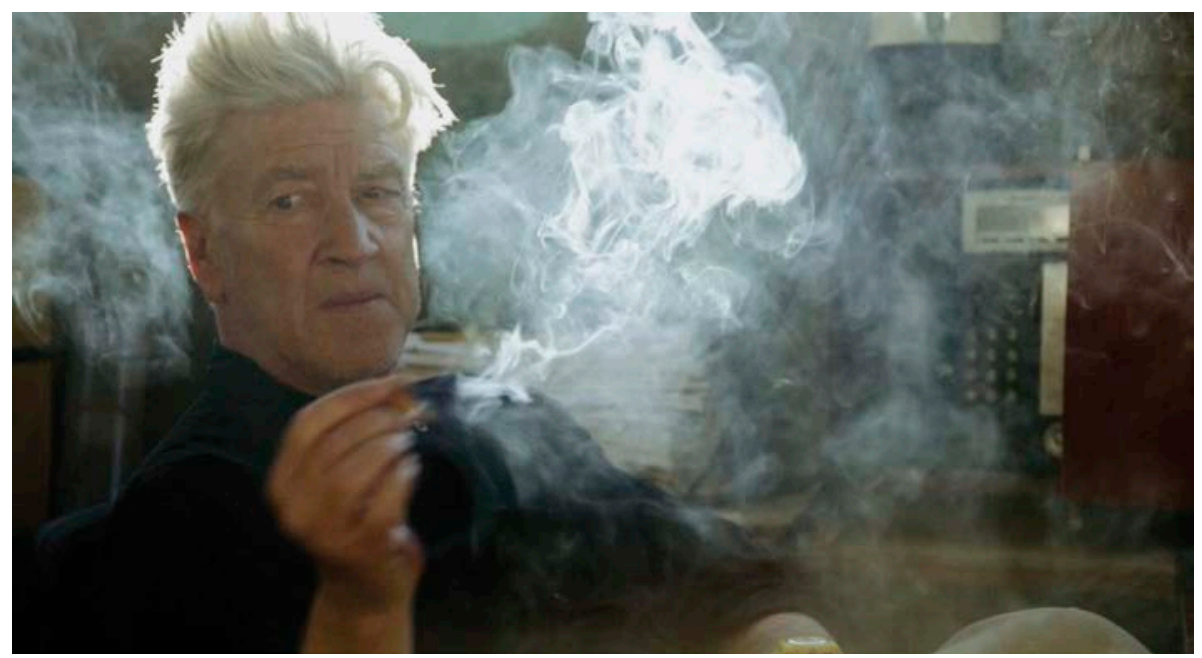

Fig.- 3. David Lynch fumando (Foto: Vértigo Films)

David Foster Wallace, lo que "alude a un tipo muy particular de ironía donde lo muy macabro y lo muy rutinario se combinan de tal forma que revelan que lo uno está perpetuamente contenido en lo otro" ${ }^{80}$ Además, a lo largo del metraje aparecen alusiones a temas que el cineasta americano tratará en su obra posterior -lo siniestro, la angustia, etc.-, hay citas visuales a algunas películas (Carretera perdida, Corazón salvaje, Eraserhead), cuando no directamente inserción de planos de sus primeros cortometrajes, etc. Concretamente, el plano de la carretera entronca con un concepto tan presente en el cine de Lynch como lo siniestro. ${ }^{81}$ Por otra parte, esa "cadencia devoradora con la que se suceden las líneas discontinuas y amarillas, engullidas por el motor" presente en los títulos de crédito de Carretera perdida (1997), de la que habla Ferrer García, es citada por Nguyen, Neergard-Holm y Barnes de manera directa. ${ }^{82}$ Concretamente, cuando Lynch recuerda un viaje por carretera en camioneta a Brooklyn, New York, en el que probó por primera vez la marihuana y en el que se quedó dormido en el carril central de la autopista. ${ }^{83}$ Estos planos de la carretera, en picado, que hacen referencia a estados de sueño, han sido basados, sin duda, en los títulos de crédito de Carretera perdida. Esa carretera, con rayas pintadas que pasan a toda velocidad, representa para Lynch "un avanzar hacia lo desconocido", 84 un desvío. ${ }^{85}$ El cineasta recuerda una imagen de su infancia que influyó claramente en Terciopelo azul: la contemplación, una noche, de una mujer desnuda, con la boca ensangrentada, de aspecto casi fantasmal (minuto 10) ${ }^{86}$. 
Se muestran fotogramas de Eraserhead, fotografías de Jack Nance, un cartel de Mulholland Drive... Además, Lynch rememora el rodaje de la película, mostrando algún fragmento del mismo y explicando cómo el vivir en los establos de la Escuela, en los que había creado los decorados de la película, le permitía imaginarse un mundo en el exterior que no existía. Al final del documental, cuando llega al momento de realizar Eraserhead, reconoce lo gratificante que le resultó hacer la película, que considera una de sus mejores obras (1:20 horas). Lo repite ante el micro, mirando hacia la izquierda del encuadre, reconcentrado, y fuma, justo antes de que aparezca en pantalla un poema conforme se van mostrando las letras al son de The Night Bell With Lightning, compuesta por el propio Lynch, que continúa tras el poema durante los títulos de crédito. Y además, contemplamos fragmentos de sus cortometrajes realizados en su etapa de formación (The Alphabet, The Grandmother), perfectamente imbricados en el relato de su periplo artístico.

Los intereses de Lynch, así como la fascinación por una atmósfera perturbadora, que será propia de su obra cinematográfica, aparecen explicitados en el documental a través de una muestra significativa de su producción pictórica y gráfica. Atmósfera que consigue creando en condiciones de gran luminosidad, como se aprecia a lo largo de los diversos momentos

80 WALLACE, David Foster (2001), Algo supuestamente divertido que nunca volveré a hacer, Barcelona, 2001, p. 194. La definición de Wallace aparece también recogida por DE FELIPE, Fernando y GÓMEZ, Iván (2017), "Je suis Laura Palmer o de cómo Twin Peaks se adelantó a su tiempo y terminó rompiéndonos el corazón", en CRISÓSTOMO y ROS, Regreso a Twin Peaks, p. 183.

81 FERRER GARCÍA, Lo siniestro como condición y límite, p. 253.

82 En esta película, que junto con Mulholland Drive e Inland Empire constituye la "trilogía de la carretera", el autor de Montana llega a un distanciamiento del MRI que "supera el simulacro de exceso neobarroco para abrir heridas profundas que reivindican el sinsentido de un discurso que no se sostiene solo". Véase SOROLLA ROMERO, Teresa (2018), Narrativas no lineales. Entre la reconstrucción del MRI fracturado y la evidencia de su artificialidad, Tesis Doctoral, Universitat Jaume I, Castellón de la Plana, p. 235.

$83 \mathrm{El}$ cineasta recuerda que las líneas blancas que iban pasando bajo la camioneta le parecían como un sueño (minuto 39:25).

84 LIM, David Lynch, p. 155.

85 En Corazón Salvaje, la autopista representa una alegoría de la libertad y la rebelión. Véase PONCE TARRÉ, "Neofiguración e iconoclasia", p. 295.

86 En ese momento aparecen reproducidas varias obras de Lynch, de aspecto siniestro y fantasmagórico, que concuerdan con los sentimientos que describe. 
en que aparece pintando. De ello dan fe los planos en los que pinta en el patio, solo o con su hija Lula (Fig. 4), o en el estudio. Además, todo ese conjunto de imágenes, de recuerdos, de sus etapas en Montana, Idaho y Virginia, a las que dedica el documental, sería fetichizado y exaltado en su obra cinematográfica. ${ }^{87} \mathrm{~A}$ todo ello hay que sumar que la misma estética de Lynch invade la obra, eso sí, "envuelta bajo el disfraz del documental" ${ }^{88}$ Por tanto, este documental se convierte en una película de gran interés para conocer al Lynch pintor, pero también para entender al Lynch cineasta. ${ }^{89}$

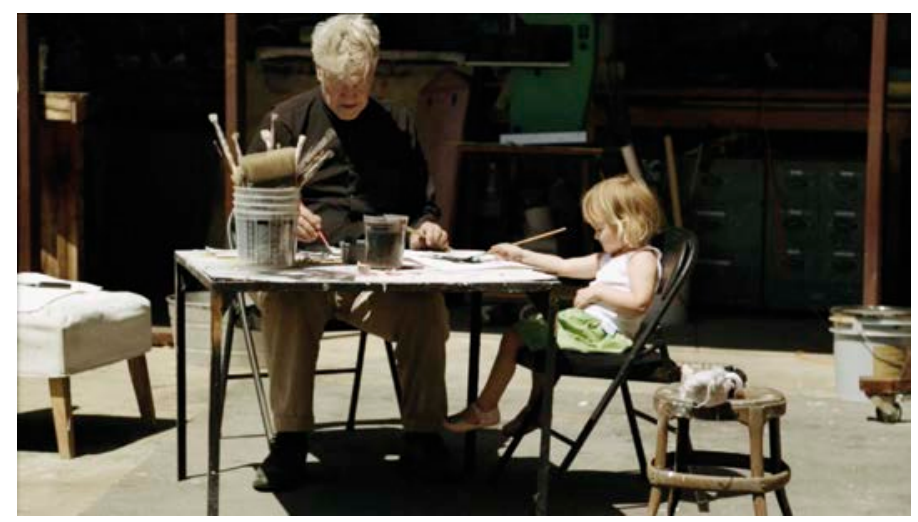

Fig.- 4. David Lynch pintando con su hija Lula (Foto: Vértigo Films)

87 BRADSHAW, "David Lynch: The Art Life review".

88 CANDIA, Santiago (2017), "David Lynch: The Art Life", Revista Otra Parte, 18/05/2017 $\mathrm{ttp} / /$ revistaotraparte.com/semanal/cine-y-tv/david-lynch-the-art-life/ (Consultado el 22/04/2018).

89 Según Bilbao, conocer al pintor es una buena manera de acercarse al cineasta. Véase BILBAO, "David Lynch: The Art Life". 


\section{Bibliografía}

ALM, David: "The Creative Pathos Of David Lynch In 'The Art Life'". Forbes, 31/03/2017 (en línea). https://www.forbes.com/sites/davidalm/2017/03/31/the-creative-pathos-of-david-lynch-in-the-art-life/\#385d03296ac0 (Consultado el 13/05/2018).

ANDERSON, Ariston: "Jon Nguyen on David Lynch: The Art Life, How Twin Peaks Delayed Production and the Downside of Kickstarter". Filmmaker Magazine, 17/05/2017 (en línea). https://filmmakermagazine. com/102444-jon-nguyen-on-david-lynch-the-art-life-how-twin-peaks-delayed-production-and-the-downside-of-kickstarter/\#.WtOMM4jwaUk (Consultado el 15/04/2017).

BARNEY, Richard A. (2009), David Lynch: Interviews, Jackson.

BILBAO, Javier: "David Lynch: The Art Life". JotDown (en línea). http:// www.jotdown.es/2017/03/david-lynch-the-art-life/

(Consultado el 14/04/2018).

BORT GUAL, Iván (2012), Nuevos paradigmas en los telones del relato audiovisual contemporáneo: partículas narrativas de apertura y cierre en las series de televisión dramáticas norteamericanas. Tesis Doctoral defendida en la Universitat Jaume I, Castellón de la Plana.

BRADSHAW, Peter: "David Lynch: The Art Life review - portrait of a filmmaker like no other". The Guardian, 14/07/2017 (en línea). https://www. theguardian.com/film/2017/jul/14/david-lynch-the-art-life-review-documentary (Consultado el 21/04/2018).

CANDIA, Santiago: "David Lynch: The Art Life". Revista Otra Parte, 18/05/2017 (en línea). http://revistaotraparte.com/semanal/cine-y-tv/ david-lynch-the-art-life/ (Consultado el 22/04/2018).

CARMONA, Luis Miguel (2008), Diccionario de compositores cinematográficos, T\&B, Madrid.

CARMONA, Luis Miguel (2012), Música \& Cine. Las grandes colaboraciones entre director y compositor, T\&B, Madrid.

CHASE, David (2017), "Los sueños del agente Cooper y de Tony Soprano", en Crisóstomo, Raquel y Ros, Enric (Coords), Regreso a Twin Peaks, Errata Naturae, Madrid, pp. 11-17.

COSTA, Jordi: "Oscuridad y esplendor". El País, $31 / 03 / 2017$ (en línea). https://elpais.com/cultura/2017/03/29actualidad/1490809056_747349.html (Consultado el 21/04/2018).

COZZOLINO, Robert (2014), David Lynch: The Unified Field, Uniersity of California Press, Oakland. 
DE FELIPE, Fernando y GÓMEZ, Iván (2017), "Je suis Laura Palmer o de cómo Twin Peaks se adelantó a su tiempo y terminó rompiéndonos el corazón", en Crisóstomo, Raquel y Ros, Enric (Coords), Regreso a Twin Peaks, Errata Naturae, Madrid, pp. 179-202.

EVANGELISTA, Chris: "Documentary 'David Lynch: The Art Life' Tells The Origin Story Of The Director [Venice Review]". The Playlist, 05/09/2016 (en línea). https://theplaylist.net/documentary-david-lynch-art-life-tells-origin-story-director-venice-review-20160905/ (Consultado el 06/05/2018). EWENS, Hannah: "What We Learned About David Lynch After Spending Three Years in His Art Cave". Vice, 05/09/2016 (en línea). https://www. vice.com/en_us/article/4w53wn/speaking-to-the-director-of-david-lynchthe-art-life-jon-nguyen (Consultado el 04/05/2018).

FERRER GARCÍA, Marcos Joaquín (2017), Lo siniestro como condición y límite del MRI. A propósito de David Lynch. Tesis Doctoral defendida en la Universitat Jaume I, Castellón de la Plana.

HALLIGAN, Fionnuala: "'David Lynch: The Art Life': Venice Review". Screen Daily, 04/09/2016 (en línea). https://www.screendaily.com/reviews/david-lynch-the-art-life-venice-review/5108847.article (Consultado el 06/05/2018).

HOLDEN, Greg (2004), Internet Babylon: Secrets, Scandals, and Shocks on the Information Superhighway, Apress, eBook.

HUDDLESTONE, Tom: "David Lynch: The Art Life". Time Out, 04/09/2016 (en línea). https://www.timeout.com/london/film/david-lynch-the-art-life (Consultado el 07/05/2018).

HUDSON, David: "Daily | Venice 2016 | David Lynch: The Art Life". Fandor, 08/09/2016 (en línea). https://www.fandor.com/posts/daily-venice2016-david-lynch-the-art-life (Consultado el 04/05/2018).

KATZ, Ephraim (1998), The Macmillan International Film Encyclopedia, Macmillan, London.

LIM, Dennis (2017), David Lynch. El hombre de otro lugar, Ediciones Alpha Decay, Barcelona.

LIVINGSTONE, Josephine: "The Organic, Violent Comedies of a Young David Lynch". The New Republic, 31/03/2017 (en línea). https://newrepublic.com/article/141771/organic-violent-comedies-young-david-lynch (Consultado el 01/05/2018).

LYNCH, David (2017), Atrapa el pez dorado, Reservoir Books, Sabadell. MACTAGGART, Allister (2010), The Film Paintings of David Lynch: Challenging Film Theory, Intellect, Bristol/Chicago. 
MEDINA, Marta: "'David Lynch: The Art Life', los orígenes de un cineasta inimitable". El Confidencial, 31/03/2017 (en línea). https://www.elconfidencial.com/cultura/cine/2017-03-31/david-lynch-the-art-life-documental_1358114/(Consultado el 21/04/2018).

MEMBA, Javier (2017), David Lynch. El onirismo de la modernidad, JC Clementine, Madrid.

MONTPELIER, Rachel: "LFF 2016 Women Directors: Meet Olivia Neergaard-Holm - "David Lynch: The Art Life". Women and Hollywood, 14/10/2016 (en línea). https://blog.womenandhollywood.com/lff2016-women-directors-meet-olivia-neergaard-holm-david-lynch-the-art-lifec5635b5890ae (Consultado el 15/04/2018).

OLSON, Greg (2008), David Lynch: Beautiful Dark, Scarecraw, Lanham.

PINTOR IRANZO, Iván (2017), "El morador del umbral, un espectador para Twin Peaks", en Crisóstomo, Raquel y Ros, Enric (Coords), Regreso a Twin Peaks, Errata Naturae, Madrid, pp. 203-2228.

PONCE TARRÉ, Jorge Esteban (2018): "Neofiguración e iconoclasia en el cine de David Lynch". H-ART, 3, pp. 273-310.

POWER, Dominic (201 1): "Surrealist cinema", en Kemp, P. (Gen. Ed.): Cinema. The hole story, London, pp. 74-75.

RODRÍGUEZ, Hilario J. (2017): "Las partículas elementales. Volverás a Twin Peaks", en Crisóstomo, Raquel y Ros, Enric (Coords), Regreso a Twin Peaks, Madrid, pp. 229-255.

ROS, Enric (2017): "Los bosques del mal. Visiones del Numen en Twin Peaks", en Crisóstomo, Raquel y Ros, Enric (Coords), Regreso a Twin Peaks, Errata Naturae, Madrid, pp. 115-135.

SOROLLA ROMERO, Teresa (2018), Narrativas no lineales. Entre la reconstrucción del MRI fracturado y la evidencia de su artificialidad. Tesis Doctoral defendida en la Universitat Jaume I, Castellón de la Plana.

VERGNE, Jean-Charles y otros (2012), Man Waking From Dream, Clermont Ferrand.

WALLACE, David Foster (2001), Algo supuestamente divertido que nunca volveré a hacer, Debolsillo, Barcelona, 2001.

YOUNG, Deborah: "'David Lynch, The Art Life': Venice Review". The Hollywood Reporter, 05/09/2016 (en línea). https://www.hollywoodreporter.com/review/david-lynch-art-life-venice-925727

(Consultado el 04/05/2018). 